\title{
Nutritive Quality of Ceanothus Shrubs in California Mixed Conifer Forest
}

JOHN G. KIE

\section{Abstract}

Mule deer (Odocoileus hemionus) in the Sierra Nevada rely heavily on mountain whitethorn (Ceanothus cordulatus, Kell.) and deerbrush ( $C$. integerrimus, $H \& A$ ) as summer forage. In this study, mountain whitethorn leaves, deerbrush leaves, and deerbush twigs were collected from shrubs growing in full sun every 2 weeks during summer, and from shrubs growing under a range of overstory crown closures during bate summer-early fall. Samples were analyzed for calcium, phosphorus, crude protein, in vitro digestible dry matter (IVDDM), gross energy, digestible energy, and sequential fibers. Summer samples of all 3 forages had adequate concentrations of calcium, apparently adequate concentrations of crude protein, and inadequate concentrations of digestible energy and phosphorus for growth and development in deer. IVDDM values were lower than expected based on fiber content alone, suggesting high concentrations of digestion-inhibiting compounds. In general, forage quality declined as summer progressed. Crown closure and shrub age had only minor effects on forage quality, but significant annual differences were found in several variables in both species. Under conditions common to the southern Sierra Nevada, annual differences in precipitation may have been more important than available light in determining forage quality. Forage deficiencies in late summer may have a substantial adverse affect on newly weaned fawns. Marginal forage quality with respect to certain nutrients suggests the need to further explore deer nutritional ecology on summer and other seasonal ranges in the Sierra Nevada.

Author is research wildlife biologist and project leader, USDA Forest Service, Pacific Southwest Forest and Range Experiment Station, 2081 E. Sierra Avenue, Fresno Calif. 93710

The author thanks Gary Eberlein, Steve Myler, Patricia Page, Jeannette Peyton, Scott Willems, and Joy Winckel for field and lab assistance, and Chuck Evans for statistical and computer assistance. Advice on the manuscript was provided by Susan Conard, Thomas Hanley, and Robert Powers. Manuscript accepted 22 May 1986.
Deerbrush (Ceanothus integerrimus, H\&A) and mountain whitethorn ( $C$. cordulatus, Kell.) are important forage species for mule deer (Odocoileus hemionus) on migratory and summer ranges in the Sierra Nevada of California. They frequently are the most abundant species present in deer diets (Hagen 1953), and are also used by cattle grazing on summer allotments.

These shrubs become established following wildfire, prescribed burning, or logging. As forest trees become reestablished, they shade out deerbrush and whitethorn shrubs (Tappeiner 1980), thereby reducing potential forage for deer. Although aspects of forage yuality were investigated as early as the 1930's (Cronemiller 1953), advances in analytical techniques (Goering and Van Soest 1970) as well as evidence of the effects of shade on forage quality in other forest browse species (Blair et al. 1983) justified further study. The purpose of this research was to compare the nutritional quality of deerbrush and mountain whitethorn shrubs (1) growing in full sun during the summer growing season, and (2) growing under a range of overstory crown closures in late summer-early fall.

\section{Materials and Methods}

\section{Study Area}

The study area was on the southeast flank of Dinkey Mountain, in the Sierra National Forest east of Fesno, California $\left(37^{\circ} 00^{\prime} \mathrm{N}\right.$, $119^{\circ} 08^{\prime} \mathrm{W}$ ) in the southern Sierra Nevada. Four sampling sites were located at about $1,700 \mathrm{~m}$ elevation in second-growth Sierra Nevada mixed conifer forest. The sites were on Shaver series soils (Pachic Ultic Haploxerolls) characterized by gentle to moderately steep slopes. The sites were within $5 \mathrm{~km}$ of each other and represented the upper elevational range of deerbrush and the lower elevational range for mountain whitethorn in the southern Sierra Nevada. Overstory tree species included white fir (Abies concolor, 
Gord. \& Glend.), ponderosa pine (Pinus ponerosa, Doug.), sugar pine ( $P$. lambertiana, Doug.), and incense cedar (Libocedrus decurrens, Torr.). The area was used by the North Kings deer herd primarily during spring (May-June) and fall (October-November) migration each year. Cattle had access to the sites from July to September.

\section{Collection of Forage Samples}

Four composite forage samples were collected every 2 weeks during summer 1983, on a separate site for each species. Sampling began on 1 June and continued through 8 September, prior to leaf abscision, in the deciduous deerbrush. Sampling of evergreen mountain whitethorn continued through 6 October. Each sample consisted of material taken from at least $\mathbf{4}$ individual shrubs growing in full sun.

Because both leaves and twigs of deerbrush are readily eaten by cattle and deer, current season's growth of both were collected, but were analyzed separately. Although whitethorn leaves are persistent, abundant new growth is available beginning in early June, and the new twig and leaf material is highly palatable. However, whitethorn twigs soon become spinescent, providing a mechanical defense to browsing by cattle. Mule deer consume whitethorn throughout the summer by picking individual leaves. Therefore, only the leaves of mountain whitethorn were collected for analysis. During the first and second collection periods, whitethorn samples contained undifferentiated new growth, in addition to leaves from the previous year.

To assess the effects of overstory crown closure on forage quality, samples were taken from 30 deerbrush shrubs in September (12 in 1982 and 18 in 1983), and 30 mountain whitethorn shrubs in October ( 10 each in 1981, 1982, and 1983) growing under a range of crown closures. These samples were collected in conjunction with a study on the influence of shrub volume and crown closure on annual production (Kie 1985). Crown closure of overstory trees was obtained by taking a photographic slide with a 35 -mm camera and a $28-\mathrm{mm}$ wide-angle lens ( $75^{\circ}$ field of view), held $1.5 \mathrm{~m}$ above the ground, pointing directly upward over each shrub sampled. The resulting slide was projected on a grid of 150 points and the percentage of points intersecting tree boles, branches, or crown was recorded as overstory crown closure. The largest basal stem of each shrub was sectioned for age determination.

\section{Nutrient and Digestibility Analyses}

All samples were oven dried at $55-60^{\circ} \mathrm{C}$. Crude protein and gross energy were determined by Kjeldahl and bomb calorimetric procedures, respectively. Calcium and phosphorus analyses were performed through atomic absorption spectrophotometry. Fortyeight hour in vitro digestible dry matter (IVDDM) was determined according to the method of Tilley and Terry (1963), using rumen inocula from cows maintained on hay diets. Results are similar to those obtained in vivo or in vitro with inocula from wild ruminants (Welch et al. 1983). Sequential detergent fiber analyses (Goering and Van Soest 1970) included neutral detergent fiber (NDF), acid detergent fiber (ADF), acid detergent lignin (ADL), and acid insoluble ash (AIA). IVDDM and fiber analyses were performed by Wildlife Habitat Management Services at Washington State University. All results were reported on a dry weight basis.

Digestible energy was estimated from gross energy and IVDDM values with the equation developed by Robbins et al. (1975:74) for white-tailed deer ( $O$. virginianus). Expected IVDDM was also calculated based on fiber content of phenolic-free forages, using the equation of Mould and Robbins (1982:27) for white-tailed deer. Nutrient concentrations were compared to recommended standards developed for penned white-tailed deer and domestic cattle.

\section{Statistical Analysis}

Analysis of covariance was used with the dependent variables measured from samples collected each fall. Unlike the summer composite samples, each fall sample represented material from a
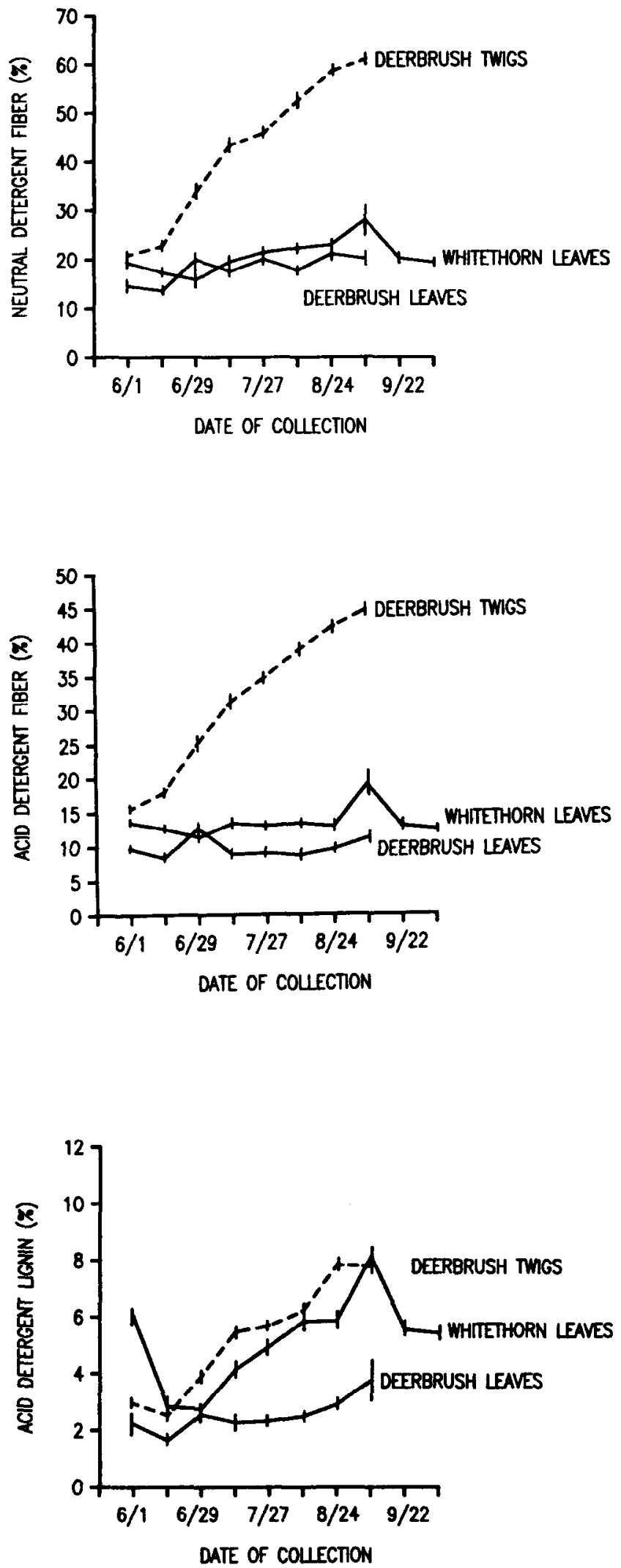

Fig. 1. Neutral detergent fiber, acid detergent fiber, and acid detergent lignin in whitethorn leaves, deerbrush leaves, and deerbrush twigs. (Vertical lines are \pm 1 standard error). 
single shrub. The model treated each dependent variable separately and examined the effects of overstory crown closure and shrub age as covariates, and the effects of year of collection as a main factor. Simple correlation coefficients were calculated for the independentdependent variable combinations determined to be significantly $(\boldsymbol{P}<0.05)$ related by the analyses of covariance.

\section{Results and Discussion}

\section{Biweekly Summer Samples}

NDF, or cell wall constituents, and ADF values were slightly higher in whitethorn leaves than in deebrush leaves, and concentrations in both species increased slightly over the summer (Fig. 1). NDF and ADF in deerbrush twigs were higher than in either of the leaf forages and increased more rapidly as the growing season progressed. The ADL values were higher in whitethorn leaves and deerbrush twigs than in deebrush leaves (Fig. 1). ADL declined in whitethorn leaves from early to mid-June, when current year's growth began to make up an increasing proportion of the sample. Subsequently, ADL values in all 3 forages increased over the summer.

Mean IVDDM values ranged from 19 to $40 \%$ for whitethorn leaves and from 47 to $64 \%$ in deerbrush leaves, the levels declining slightly over the summer (Fig. 2). The decline was sharper in deerbrush twigs, ranging from $64 \%$ early in the season to $16 \%$ by early September. Although IVDDM values were low compared to
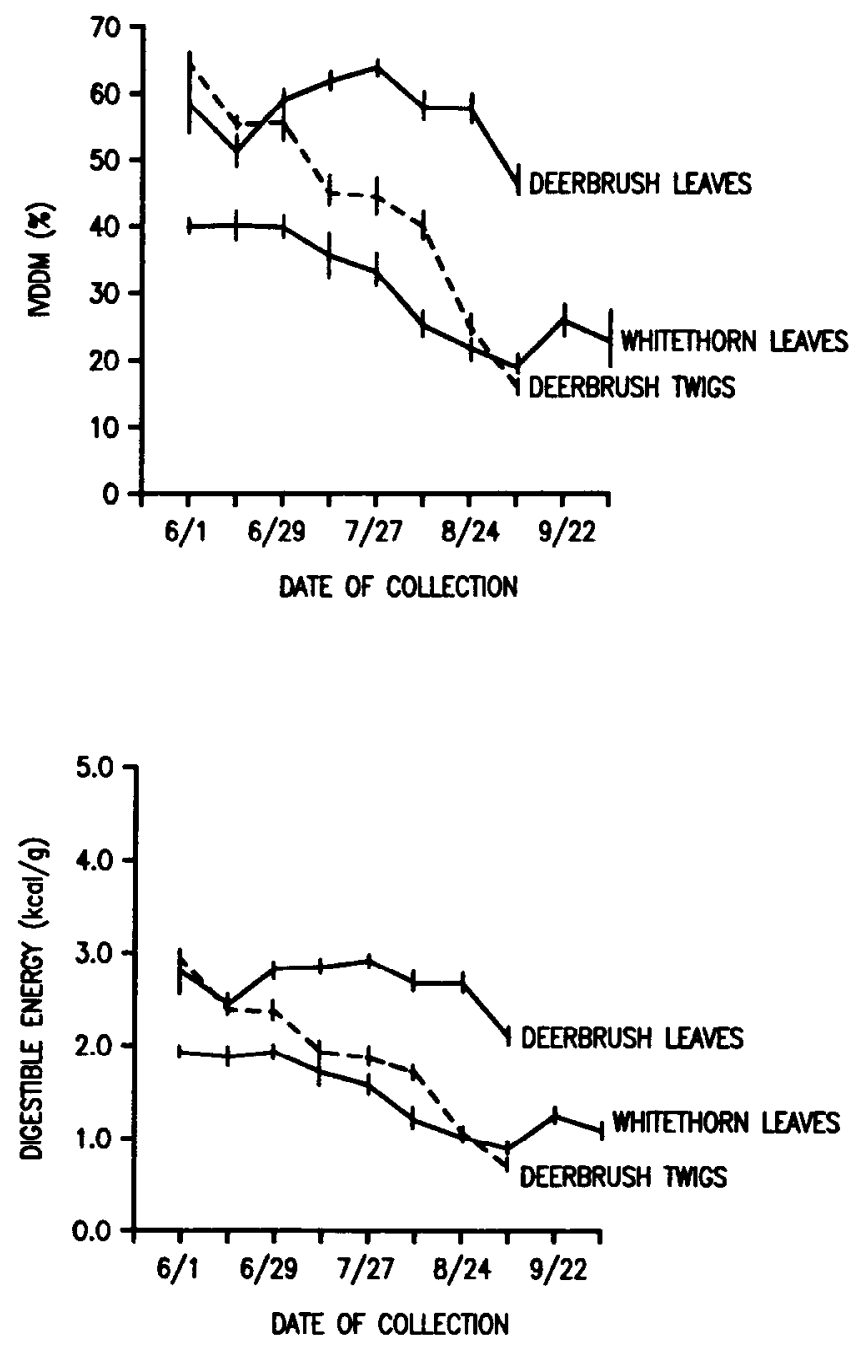

Fig. 2. In vitro digestible dry matter (IVDDM) and digestible energy in whitethorn leaves, deerbrush leaves, and deerbrush twigs. (Vertical lines are \pm 1 standard error). high-quality herbaceous forage, they were similar to values reported for other forest shrub species (Hanley and McKendrick 1983, Leslie et al. 1984).

Observed IVDDM values were lower than expected based on fiber content of forages relatively free of digestion-inhibiting phenolic compounds (Mould and Robbins 1982). Expected IVDDM values ranged from 62 to $78 \%$ for whitethorn leaves, 73 to $80 \%$ for deerbrush leaves, and 57 to $78 \%$ for deerbrush twigs. Soluble phenolics, a broad class of secondary plant compounds, suppress the digestion of neutral detergent solubles, thereby lowering IVDDM values (Mould and Robbins 1982). Some forest shrubs in southeast Alaska exhibited IVDDM values as low as two-thirds of that expected based on fiber content, suggesting high concentrations of digestion inhibitors (Hanley and McKendrick 1983).

Cronemiller (1953) reported high concentrations of saponin in deerbrush in early fall, suggesting this as a cause for decreased palatability and occasional nervous system disorders in cattle. Conversely, Countryman (1982) found acetone solvent extractives averaged only $7.7 \%$ in mountain whitethorn foliage. This value was comparable to acetone-extracted total phenolics for most forages categorized as low-phenolic by Mould and Robbins (1982).

Gross energy remained constant throughout the summer at $\mathbf{4 . 6}$ to $5.0 \mathrm{kcal} / \mathrm{g}$ in whitethorn and deerbrush leaves and 4.3 to 4.6 $\mathrm{kcal} / \mathrm{g}$ in deerbrush twigs. Because IVDDM declined during the summer, digestible energy, estimated from gross energy and IVDDM, declined also. At digestible energy concentrations below $2.17 \mathrm{kcal} / \mathrm{g}$, total energy intake by white-tailed deer is constrained by the physical capacity of their digestive systems (Ammann et al. 1973). The NRC (1976) recommended standard for lactating beef cattle is $2.3 \mathrm{kcal} / \mathrm{g}$ of digestible energy (based on the requirement of $1.9 \mathrm{kcal} / \mathrm{g}$ of metabolizable energy, plus the energy used in urine and methane production). Digestible energy values were below these standards season-long in whitethorn leaves, after early September in deerbrush leaves, and after early July in deerbrush twigs (Fig. 2). In addition, concentrations of oils, such as those found at low levels in whitethorn leaves by Countryman (1982), can inflate the estimation of digestible energy because of their high gross energy content.

Crude protein concentrations were highest in deerbrush leaves and twigs and declined during the summer (Fig. 3). Crude protein

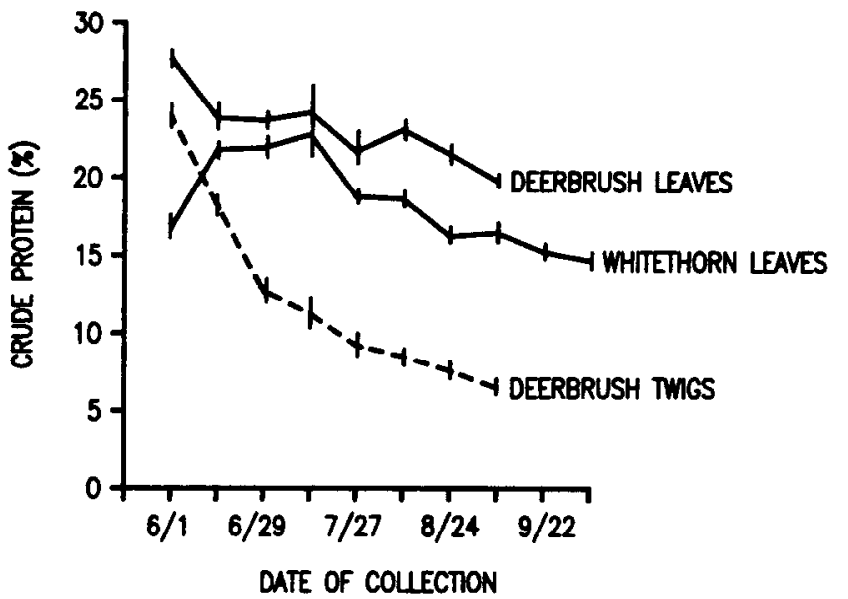

Fig. 3. Crude protein in whitethorn leaves, deerbrush leaves, and deerbrush twigs. (Vertical lines are $\pm I$ standard error).

in whitethorn leaves increased with the addition of new growth in mid-June, and then also declined. Although crude protein concentrations as low as $9 \%$ are sufficient for maintenance in adult white-tailed deer, the requirement for maximum growth ranges from 13 to $16 \%$ for adults and up to $20 \%$ for weaned fawns (French et al. 1956, McEwen et al. 1957, Ullrey et al. 1967). The NRC (1976) crude protein standard for lactating cattle is $9.2 \%$ (the digestible protein standard is $5.4 \%$ ). Crude protein concentrations in both 
Table 1. Means and standard errors (SE) for nutrient variables in whitethorn leaves $(n=30)$ collected during fall 1981, 1982, and 1983, and in deerbrush leaves $(n=30)$ and deerbrush twigs $(n=30)$ collected during fall 1982 and 1983.

\begin{tabular}{|c|c|c|c|c|}
\hline Variable & & $\begin{array}{l}\text { Whitethorn Leaves } \\
\text { Mean (SE) }\end{array}$ & $\begin{array}{c}\text { Deerbrush Leaves } \\
\text { Mean (SE) }\end{array}$ & $\begin{array}{c}\text { Deerbrush Twigs } \\
\text { Mean (SE) }\end{array}$ \\
\hline Neutral detergent fiber (\%) & $\begin{array}{l}\text { 1981: } \\
\text { 1982: } \\
\text { 1983: }\end{array}$ & $\begin{array}{l}27.90(0.80) \\
28.34(1.61) \\
25.49(2.24)\end{array}$ & $\begin{array}{c}33.66(1.92) \\
29.38(1.39)\end{array}$ & $\begin{array}{c}- \\
65.48 *(2.25) \\
53.17 *(1.05)\end{array}$ \\
\hline Acid detergent fiber (\%) & $\begin{array}{l}\text { 1981: } \\
\text { 1982: } \\
\text { 1983: }\end{array}$ & $\begin{array}{l}14.11(0.50) \\
16.95(1.13) \\
14.59(1.50)\end{array}$ & $\begin{array}{c}- \\
19.85^{*}(1.71) \\
14.65^{*}(0.89)\end{array}$ & $\begin{array}{c}- \\
48.42 *(2.02) \\
38.95 *(0.88)\end{array}$ \\
\hline Acid detergent lignin (\%) & $\begin{array}{l}\text { 1981: } \\
\text { 1982: } \\
\text { 1983: }\end{array}$ & $\begin{array}{l}7.95 *(0.48) \\
9.49 *(0.91) \\
6.27 *(0.50)\end{array}$ & $\begin{array}{r}10.31 *(1.38) \\
5.90 *(0.66)\end{array}$ & $\begin{array}{c}- \\
15.63^{*}(1.57) \\
8.45^{*}(0.29)\end{array}$ \\
\hline IVDDM (\%) & $\begin{array}{l}\text { 1981: } \\
\text { 1982: } \\
\text { 1983: }\end{array}$ & $\begin{array}{l}36.82^{*}(0.91) \\
29.06 *(1.54) \\
35.03^{*}(1.27)\end{array}$ & $\begin{array}{c}- \\
53.93 *(3.64) \\
63.60 *(1.38)\end{array}$ & $\begin{array}{c}33.49(1.70) \\
35.14(1.40)\end{array}$ \\
\hline Digestible energy (kcal/g) & $\begin{array}{l}\text { 1981: } \\
\text { 1982: } \\
\text { 1983: }\end{array}$ & $\begin{array}{l}1.86^{*}(0.05) \\
1.44^{*}(0.08) \\
1.73^{*}(0.07)\end{array}$ & $\begin{array}{c}- \\
2.42 *(0.18) \\
2.93 *(0.06)\end{array}$ & $\begin{array}{c}- \\
1.48(0.08) \\
1.56(0.06)\end{array}$ \\
\hline Crude protein (\%) & $\begin{array}{l}\text { 1981: } \\
\text { 1982: } \\
\text { 1983: }\end{array}$ & $\begin{array}{l}13.18(0.33) \\
14.12(0.18) \\
13.62(0.33)\end{array}$ & $\begin{array}{c}- \\
18.15^{*}(0.43) \\
16.92 *(0.30)\end{array}$ & $\begin{array}{c}- \\
8.22 *(0.34) \\
7.77 *(0.23)\end{array}$ \\
\hline Calcium (\%) & $\begin{array}{l}\text { 1981: } \\
\text { 1982: } \\
\text { 1983: }\end{array}$ & $\begin{array}{l}1.08(0.10) \\
1.13(0.04) \\
1.01(0.05)\end{array}$ & $\begin{array}{c}- \\
3.66 *(0.47) \\
2.33 *(0.10)\end{array}$ & $\begin{array}{c}- \\
1.27 *(0.10) \\
1.07 *(0.05)\end{array}$ \\
\hline Phosphorus (\%) & $\begin{array}{l}\text { 1981: } \\
\text { 1982; } \\
\text { 1983; }\end{array}$ & $\begin{array}{l}0.14 *(0.01) \\
0.17 *(0.01) \\
0.17 *(0.01)\end{array}$ & $\begin{array}{l}- \\
0.18(0.01) \\
0.19(0.01)\end{array}$ & $\begin{array}{c}- \\
0.16^{*}(0.01) \\
0.12^{*}(0.01)\end{array}$ \\
\hline
\end{tabular}

-Significant ( $P<0.05$ ) difference with respect to year of collection (after adjustment for overstory crown closure and shrub age).

leaf forages were well above these levels.

Crude protein concentrations were known to be high in both deerbrush and whitethorn leaves (Hagen 1953). However, phenolic compounds can greatly lower protein digestibility (Mould and Robbins 1982). Furthermore, only about 60 to $80 \%$ of total plant nitrogen (the basis on which crude protein is calculated) is tied up as true protein (Van Soest 1982). Powers (personal communication) found true protein (based on trichloroacetic acid soluble nitrogen) in 3 samples of deerbrush leaves collected in early summer averaged only $80 \%$ of crude protein. As with digestible energy values, additional research is needed on digestible protein content in shrubs over a range of sites (Hanley and McKendrick 1985).

Calcium values in all 3 forages were high and increased in both whitethorn and deerbrush leaves during the summer (Fig. 4). Calcium requirements for optimum growth and antler development in white-tailed deer were estimated at $0.64 \%$ (McEwen et al. 1957). A concentration of $0.40 \%$ was considered adequate for normal development of fawns (Ullrey et al. 1973). The recommended standard for lactating beef cows is $0.28 \%$ calcium (NRC 1976). All 3 forages exceeded these standards by wide margins.

Phosphorus values began at moderate levels but declined steadily as the summer progressed (Fig. 4). Phosphorus requirements for optimum growth and antler development in white-tailed deer may range as high as $0.56 \%$ (McEwen et al. 1957). Dietary concentrations of $0.26 \%$ phosphorus were considered adequate for weaned fawns (Ullrey et al. 1975). The NRC (1976) recommended standard for lactating cattle is $0.28 \%$ phosphorus. By late July, phosphorus concentrations in whitethorn leaves, deerbrush leaves, and deerbrush twigs had all dropped below these levels. As a result of high calcium and low phosphorus concentrations, high calcium:phosphorus ratios may further exacerbate phosphorus deficiencies.

The pattern of phosphorus deficiency and excess calcium was reported earlier for deerbrush (Cronemiller 1953), and was also
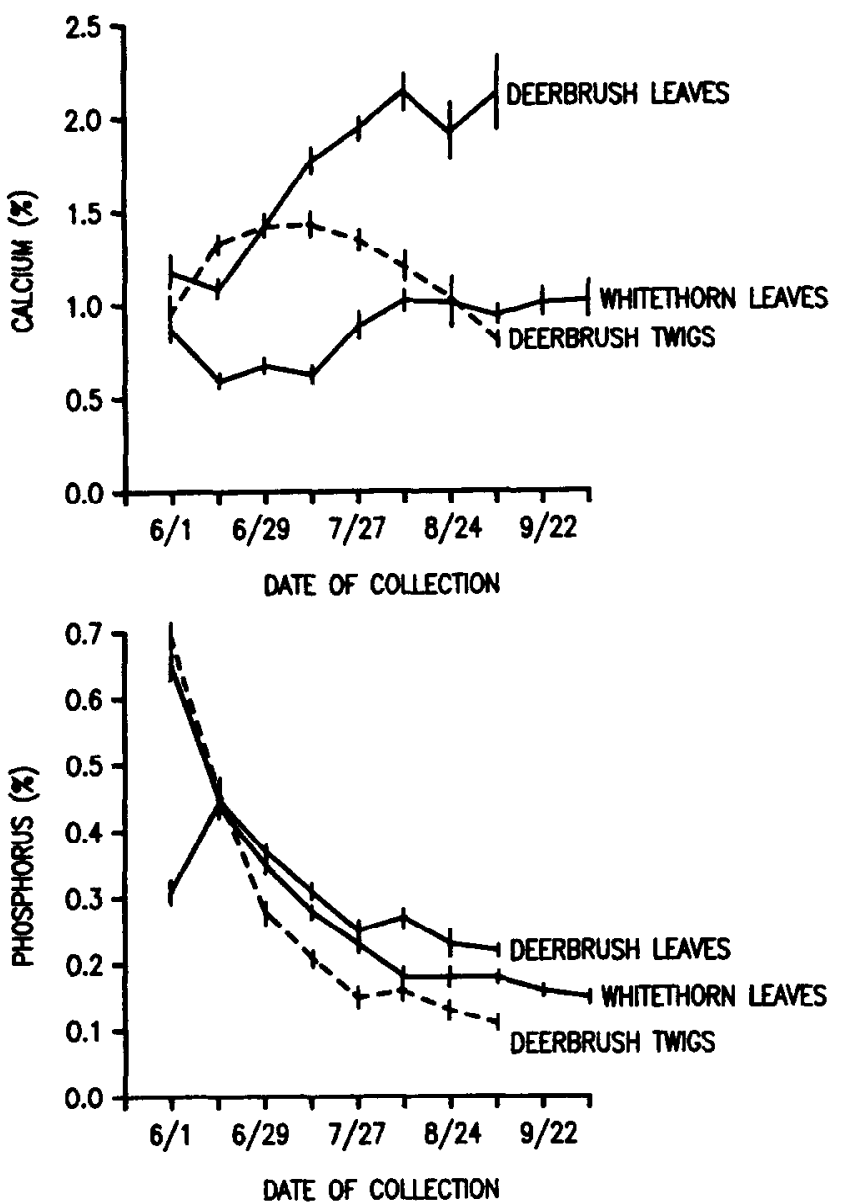

Fig. 4. Calcium and phosphorus in whitethorn leaves, deerbrush leaves, and deerbrush twigs. (Vertical lines are \pm 1 standard error). 
found in forest shrubs in southeast Alaska (Hanley and McKendrick 1983). Seasonally low phosphorus values were also reported for forest shrubs eaten by deer in Washington (Leslie et al. 1984).

\section{Late Summer-Early Fall Samples}

In whitethorn leaves, significant $(P<0.05)$ yearly differences were found in ADL, IVDDM, digestible energy, and phosphorus (Table 1). The 1982 samples were characterized by high ADL, low IVDDM, and low digestible energy. Heavy spring snowfall remained on the study area late into summer 1982, delaying plant growth for several weeks. The 1982 samples were higher in ADL and lower in IVDDM, contrary to what would be expected from samples collected at an earlier phenological stage. This suggests a complex interaction between weather conditions and changes in nutrient content in mountain whitethorn.

In deerbrush leaves, significant differences between years were found in ADF, ADL, IVDDM, digestible energy, crude protein, and calcium (Table 1). In deerbrush twigs, there were yearly differences in NDF, ADF, ADL, crude protein, calcium, and phosphorus. No 1981 deerbrush samples were available for comparison, although differences between 1982 and 1983 followed a pattern similar to that in whitethorn leaves (high lignin, low IVDDM, and low digestible energy).

The whitethorn shrubs collected during the fall averaged 9.6 years of age (range 5-20 years) and grew under an average overstory crown closure of $27 \%$ (range 6-71\%). Shrub age had no significant $(P>0.05)$ effect on any dependent variable in whitethorn leaves. Crude protein increased significantly with increasing overstory crown closure but the relationship was weak $\left(r^{2}=0.15\right)$. As crown closure increased, significant declines were noted in both IVDDM $\left(r^{2}=0.13\right)$ and digestible energy $\left(r^{2}=0.14\right)$.

Deerbrush shrubs collected during the fall averaged 7.7 years of age (range 2-14 years) and grew under an average overstory crown closure of $33 \%$ (range $0-72 \%$ ). Overstory crown closure had no effect on any dependent variable in either deerbrush leaves or twigs. In deerbrush leaves, crude protein decreased significantly $(P<0.05)$ with shrub age $\left(r^{2}=0.10\right)$. In deerbrush twigs, NDF decreased with shrub age $\left(r^{2}=0.10\right)$. As with whitethorn leaves, these relationships, although significant, were characterized by very low correlation coefficients.

Overstory effects on nutrient content of forest shrubs have not been well identified. Bitterbrush (Purshia tridentata) growing under natural stands of ponderosa pine in Oregon had higher ash and nitrogen-free extract concentrations and lower crude fiber than shrubs growing under thinned stands (Dealy 1966). Deepening shade resulted in increased crude protein, NDF, ADF, ADL, cellulose, calcium, and phosphorus in young plants of several southern browse species when grown under greenhouse conditions (Blair 1982, Blair et al. 1983). Increasing shade also resulted in declines in total nonstructural carbohydrates, IVDDM, neutral detergent solubles, and digestible energy in some species. Overstory characteristics were unrelated to crude protein, gross energy, and IVDDM in understory browse plants in loblolly pine (Pinus taeda) plantations in Virginia (Conroy et al. 1982).

Alaska blueberry (Vaccinium alaskensis) and bunchberry dogwood (Cornus canadensis) growing under open overstories in Alaska had greater concentrations of phenolics and total nonstructural carbohydrates and lower concentrations of crude protein and phosphorus than did plants growing under well developed overstories (Hanley et al. 1985). The differences may have been related to the availability of light, nutrients and the carbon:nutrient balance in the shrubs (Hanley et al. 1985).

Few overstory effects were seen in this study. Total precipitation is low, much of it falls as snow in the winter, and summer soil moisture conditions vary greatly from year to year in the southern Sierra Nevada. The results indicate that on these sites, total precipitation and available soil moisture might be more important than available light in determining plant nutrient content.

\section{Conclusions and Management Recommendations}

Neither mountain whitethorn nor deerbrush alone appeared to provide sufficient nutrients for optimum growth and development in mule deer. Particularly deficient were concentrations of phosphorus, digestible energy, and perhaps digestible protein. Also, digestion-inhibiting compounds may have been present in high levels. However, leaves of both species provide high concentrations of calcium and neutral detergent solubles. Such forages are valuable when consumed along with other species (Vangilder et al. 1982).

Mule deer rely heavily on browse, particularly mountain whitethorn, on summer ranges in the southern Sierra Nevada. They eat other forages, but recent studies have uncovered similar deficiencies (for example, in phosphorus concentrations) in meadow grasses, sedges, and forbs as well (Kie, unpub. data on file). Additional information on intake rates and the use of modeling techniques would provide insights on the relationships between quantity and quality (Hobbs and Swift 1985). The apparent deficiencies in several nutrients among both species of ceanothus and the uncertainty about total nutritional intake are sufficient to justify additional research on deer nutritional ecology in the Sierra Nevada.

Information is needed on nutrient intake on other seasonal ranges. For example, if deer can accumulate phosphorus during seasons of abundance, annual intake may be adequate despite deficiencies during part of the year (Hanley and McKendrick 1985). However, maturing trends in plant communities on spring migration and early summer ranges and declining nutritional quality may have been the ultimate cause of a long-term decline of the North Kings deer herd where this current study was done. If forage plants on both spring and summer ranges are deficient in some nutrients, then winter forage plants may be critical in balancing year-long nutritional needs of adult deer. In any case, late summer forage deficiencies may have a substantial adverse affect on newly weaned fawns.

Based on current findings, management plans for deer summer ranges should recognize the need for and provide a diversity of forages as well as productive stands of mountain whitethorn and deerbrush. However, opportunities to manipulate overstory stand structure as a mechanism to influence understory browse quality appear to be limited, particularly in light of annual variations caused by differences in weather patterns.

\section{Literature Cited}

Ammann, A.P., R.L. Cowan, C.L. Mothershead, and B.R. Baumgardt. 1973. Dry matter and energy intake in relation to digestibility in whitetailed deer. J. Wildl. Manage. 37:195-201.

Blair, R.M. 1982. Growth and nonstructural carbohydrate content of southern browse species as influenced by light intensity. J. Range Manage. 35:756-760.

Blaîr, R.M., R. Alcaniz, and A. Harrell. 1983. Shade intensity influences the nutrient quality and digestibility of southern deer browse leaves. $J$. Range Manage. 36:257-264.

Conroy, M.J., R.G. Oderwald, and T.L. Sharik. 1982. Forage production and nutrient concentrations in thinned loblolly pine plantations. J. Wildl. Manage. 46:719-727.

Countryman, C. 1982. Physical characteristics of some northern California brush fuels. USDA Forest Serv., Gen. Tech. Rep. PSW-61. Berkeley, CA.

Cronemiller, F.P. 1953. Deerbrush (sweetbirch) in California. USDA Forest Serv., Region 5. San Francisco, Calif.

Dealy, J.E. 1966. Bitterbrush nutrition levels under natural and thinned ponderosa pine. USDA Forest Serv., Res. Note PNW-33. Portland, OR.

French, C.E., L.C. McEwen, N.D. Magruder, R.H. Ingram, and R.W. Swift. 1956. Nutrient requirements for growth and antler development in the white-tailed deer. J. Wildl. Manage. 20:221-232.

Goering, H.K., and P.J. Van Soest. 1970. Forage fiber analyses (apparatus, reagents, procedures, and some applications). USDA Agr. Handb. 379, Washington, D.C. 
Hagen, H.L. 1953. Nutritive value for deer of some forage plants in the Sierra Nevada. California Fish and Game 39:163-175.

Hanley, T.A., and J.D. McKendrick. 1983. Seasonal changes in chemical composition and nutritive value of native forages in a spruce-hemlock forest, southeastern Alaska. USDA Forest Serv., Res. Paper PNW-312. Portland, Ore.

Hanley, T.A., and J.D. McKendrick. 1985. Potential nutritional limitations for black-tailed deer in a spruce-hemlock forest, southeastern Alaska. J. Wildl. Manage. 49:103-114.

Hanley, T.A., R.G. Cates, B. Van Horne, and J.D. McKendrick. 1985. Forest stand age-related differences in apparent nutritional quality of forage for deer in southeastern Alaska. paper presented at 4th Annual Wildland Shrub Symposium, 7-9 August 1985, Snowbird, Utah. In press.

Hobbs, N.T., and D.M. Swift. 1985. Estimates of habitat carrying capaity incorporating explicit nutritional constraints. J. Wildl. Manage. 49:814-822.

Kie, J.G. 1985. Production of deerbrush and mountain whitethorn related to shrub volume and overstory crown closure. USDA Forest Service, Res. Note PSW-377. Berkeley, Calif.

Leslie, D.M., E.E. Starkey, and M. Vavra. 1984. Elk and deer diets in old-growth forests in western Washington, J. Wildl. Manage. 48:762-775.

McEwen, L.C., C.E. French, N.D. Magruder, R.W. Swift, and R.H. Ingram. 1957. Nutrient requirements of the white-tailed deer. Trans. $N$. Amer. Wildl. Conf. 22:119-132.

Mould, E.D., and C.T. Robbins. 1982. Digestive capabilities in elk compared to white-tailed deer. J. Wildl. Manage. 46:22-29.
NRC. 1976. Nutrient requirements of beef cattle, 5th ed. Nat. Res. Counc., Nat. Acad. Sci.

Robbins, C.T., P.J. Van Soest, W.W. Mautz, and A.N. Moen. 1975. Feed analyses and digestion with reference to white-tailed deer. J. Wildl. Manage. 39:67-79.

Tappeiner, J.C. II. 1980. Sierra Nevada mixed conifer. p. 118-119. In: F.H. Eyre (Ed.), Forest cover types of the United States and Canada. Soc. Amer. Forest., Washington, DC.

Tilley, J.M.A., and R.A. Terry. 1963. A 2-stage technique for the in-vitro digestion of forage crops. J. Brit. Grassl. Soc. 18:104-111.

Ullrey, D.E., W.G. Youatt, H.E. Johnson, L.D. Fay, and B.L. Bradley. 1967. Protein requirement of white-tailed deer fawns. J. Wildl. Manage. 31:679-685.

Ulirey, D.E., W.G. Yountt, H.E. Johnson, L.D. Fay, B.L. Schoepke, W.T. Magee, and K.K. Kenhey. 1973. Calcium requirements of weaned whitetailed deer fawns. J. Wildl. Manage. 37:187-194.

Ullrey, D.E., W.G. Youatt, H.E. Johnson, A.B. Cowan, L.D. Fuy, R.L. Covert, W.T. Magee, and K.K. Keahey. 1975. Phosphorus requirements of weaned white-tailed deer fawns. J. Wildl. Manage. 39:590-595.

Vangilder, L.D., O. Torgerson, W.R. Porath. 1982. Factors influencing diet selection by white-tailed deer. J. Wildl. Manage. 46:711-718.

Van Soest, P.J. 1982. Nutritional ecology of the ruminant. O\&B Books, Corvallis, Ore.

Welch, B.L., J.C. Pederson, and W.P. Clary. 1983. Ability of different rumen inocular to digest range forages. J. Wildl. Manage. 47:873-877.

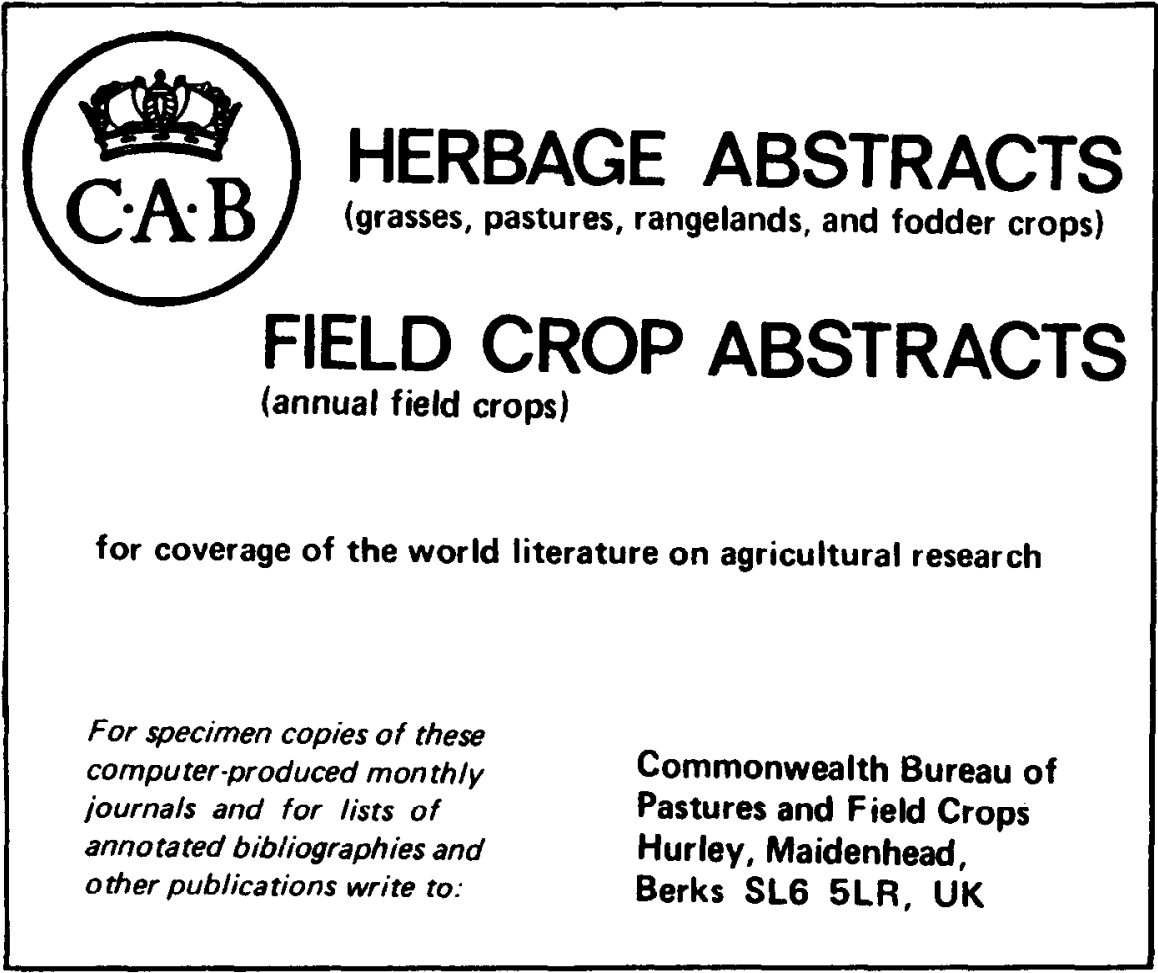

